\title{
Obraz cudzoziemskich żołnierzy w piśmiennictwie wojskowym XVI wieku
}

Marek Plewczyński 
NAP7S Seria VII 2001

\section{Marek Plewczyński}

\section{Obraz cudzoziemskich żołnierzy w piśmiennictwie wojskowym XVI wieku}

W świadomości szesnastowiecznego społeczeństwa szlacheckiego funkcjonowały stereotypy cudzoziemskiego żołnierza. Miały one istotny wpływ na kształtowanie się struktury społeczno-narodowościowej armii koronnej w Rzeczypospolitej Obojga Narodów. Kreując obraz „cudzoziemskości”, teoretycy i dowódcy wojskowi zastanawiali się bowiem, kto ma uczestniczyć w walce zbrojnej - czy tylko szlachta, czy i inne warstwy społeczne, w tym i przedstawiciele obcych nacji. Kwestia była ważna, a dotyczyła koncepcji armii zaciężnej - czy ma być ona narodowa, czy też mają w niej służyć cudzoziemcy w oddziałach najemnych i zaciężnych.

Zagadnienie stosunku pisarzy do cudzoziemców dotyczy nie tylko wąskiej grupy traktatów teoretyczno-wojskowych odnoszących się do sztuki wojennej i techniki wojskowej, ale również opracowań, które rozpatrują sprawy wojska w szerszym aspekcie zjawisk politycznych, społecznych, prawnych i ekonomicznych. Stąd potrzeba przyjrzenia się przynajmniej niektórym pracom politycznym (na przykład Andrzeja Frycza Modrzewskiego, Krzysztofa Warszewickiego czy Józefa Wereszczyńskiego), w których występuje problem niepolskiego żołnierza. Cele dydaktyczne i poznawcze miały jednak przede wszystkim rozprawy teoretyczno-wojskowe ${ }^{1}$. By umieć zwal-

\footnotetext{
I O uwarunkowaniach ekonomicznych, społecznych i politycznych w piśmicnnictwic wojskowym pisał przede wszystkim Karol Olejnik. W pracy Rozwoój polskiej mysti wojskowej do końca XVII wieku, Poznań 1976, ukazał rozbicżności między myślą wojskową a praktyką pola walki. Wpływ czynników społcczno-politycznych na skład narodowościowy wojska polskicgo za ostatnich Jagiellonów badał M. Plcwczyński, $W$ służbie polskiego króla. $Z$ zagadnień struktury narodowościowej armii koronnej $w$ latach 1500-1574, Sicdlce 1995, s. 220-233; idcm, Uwarunkowania obcych zaciggów w Polsce $w$ XVI wieku, w: Od armii komputowej do narodowej (XVI-XX w.), red. Z. Karpus, W. Rczmcr, Toruń 1998, s. 7-16. Historycy wojskowi zajmowali siç głównie dziejami piśmiennictwa technicznego i ogólnowojskowcgo pod kątem praktycznej przydatności na polu walki lub odtwarzali warsztat naukowy pisarzy wojskowych. Por. m.in.: J. Sikorski, „Ksiegi hetmańskie” Stanisława Sarnickiego na tle piśmiennictwa wojskowego w Polsce XVI wieku, ,Studia i Materiały do Historii Wojskowości" (dalej: SMHW) 1966, t. 12, cz. 2, s. 3-69; SMHW 1967, t. 13, cz. 1, s. 3-62; idem, Polskie piśmiennictwo wojskowe od XV do XX wieku, Warszawa 1991; T. M. Nowak, Polskie wojskowe piśmiennictwo techniczne do roku 1764, Warszawa 1961; idem, Z problematyki staropolskiego piśmiennictwa wojskowego, SMHW 1986,
} 
czać nieprzyjaciól, trzeba było znać wojskowość państw ościennych - Turcji, Krymu, Moskwy, Mołdawii i Niemiec. Dlatego też skupiano uwagę na pewnych cechach charakterystycznych dla strategii, taktyki, wyszkolenia, bojowości, wyposażenia i uzbrojenia naszych sąsiadów. W ten sposób autorzy kształtowali również opinie i nastroje społeczne o cudzoziemskich żołnierzach.

Zarówno literatura polityczna i publicystyka, jak i piśmiennictwo wojskowe XVI wieku, rozwijały się w dużej mierze pod wpływem niebezpieczeństwa turecko-tatarskiego. Już Serb w służbie tureckiej, Konstanty Michajłowicz z Ostrawicy, w swych Pamiętnikach janczara..., rozpowszechnionych w Polsce na początku XVI wieku, podkreślał doskonałe uzbrojenie Turków, ich szybkość, niesłychaną dyscyplinę, biegłość w zdobywaniu twierdz, zaciekłość szturmów, odwagę i sprawność ${ }^{2}$. Pamiętniki janczara..., nawolujące do obrony przed Turkami, oddziałały na późniejszych pisarzy zajmujących się taktycznymi problemami walki z przeciwnikiem wschodnim. Jeszcze Stanisław Sarnicki w latach siedemdziesiątych XVI wieku pisał, że motywem, który skłonił go do napisania Ksiaghetmaniskich, było szkolenie wszystkich narodów języka słowiańskiego, by nie cierpiały od „przeklętych barbarów psiej krwie tatarskiej”. Wpływ niebezpieczeństwa tureckiego na piśmiennictwo polityczne widać zwłaszcza w latach czterdziestych XVI wieku. Stanisław Orzechowski w swych "turcykach” 3 liczyl, że polską jazdę pospolitego ruszenia wesprą władcy chrześcijańscy tymi rodzajami wojska, które są u nich najliczniejsze i jakościowo najlepsze. Cesarstwo miało więc dostarczyć piechotę, Moskwa artylerię, a Wenecja flotę. Stawiając na szlachecką jazdę, Orzechowski nie dostrzegał przemian na polu walki ani umiejętności oblężniczych Turków. Uważał zresztą, że w krytycznej chwili służący pod przymusem w armii tureckiej podbici chrześcijanie z pewnością odstąpią od sułtana.

Pogląd o wyższości armii narodowych nad wielonarodowościowymi podzielał też ówczesny hetman wielki koronny. Informują nas o tym Jana Tarnowskiego rozmowy o prowadzeniu wojny $z$ Turkami odbyte $z$ posłem króla rzymskiego Ferdynanda I Habsburga, Strazjuszem, w 1542 roku ${ }^{4}$. Hetman przewidywał, że w wyprawie przeciwko Turkom do żołnierzy cesarskich z Niemiec, Włoch i Hiszpanii dołączą Czesi, Morawianie, Ślązacy i część Węgrów. Za najgorsze uważał w wojsku chrześcijańskim to, że służą w nim różne narody odmienne duchem, mową i obyczajami. Jeden naród nienawidzi drugiego. Rodzą się konflikty, w czasie których poszczególne nacje z trudem powstrzymują się od walki między sobą. Również ich dowódcy zebrani z różnych narodowości są wrogo do siebie nastawieni. Kłótnie mogą doprowadzić do rozproszenia się całego wojska. Tarnowski ocenił też negatywnie zachodnio-europejskie wojsko za brak dyscypliny, skłonność do łupiestw i grabieży, zbytek i nierząd, z którego rodzą się „rozmaite niegodziwości

t. 29, s. 43-71; idem, Polskie thumaczenia europejskiej literatury wojskowej dokonane w XVI-XVIII wieku, Warszawa 2000.

2 Zob. [Konstanty z Ostrowicy], Pamiętniki janczara czyli kronika turecka Konstantego z Ostrouvicy napisana między $r .1496$ a 1501, wyd. J. Łoś, Kraków 1912, s. 135-142; por. M. Plewczyński, Wkład Serbów w rozwój staropolskiej wojskowości (1450-1570), SMHW 1994, t. 36, s. 7, 11.

${ }^{3}$ Zob. S. Orzechowski, Ksiqżki... o ruszeniu ziemie polskiej przeciw Turkoui, z tacińskiego języka na polski wylożone, każdemu rycerskiemu człowiekowi pożyteczne, Kraków 1543; idem, Dziela, t. 1-2, Mowy, Wrocław 1826; J. Sikorski, Problematyka walki $z$ Turkami w polskiej literaturze wojskowej i politycznej XVI-XVII w., SMHW 1984, t. 27, s. $147-151$.

4 Zob. Z. Spieralski, Jana Tarnowskiego rozmowa o prowadzeniu wojny z Turkami (1542), SMHW 1986, t. 29, s. $287-312$. 
i haniebna słabość". Uwagi hetmańskie dotyczące żołnierskiego wyżywienia odnoszą się bardziej do głodu panującego w szeregach niż krytykowanego obżarstwa:

W chrześcijańskim bowiem wojsku żołnierze, jak tylko mogą najprędzej, piją zaraz wodę, pożerają chciwie bydło, świeżo ze skóry obdarte i jeszcze ciepłe, a także owce. Wywołuje to często ociężałość, a wkrótce chwyta ich gorączka, biegunka $\mathrm{i}$ inne choroby $(\ldots)^{5}$.

Ale i wojska tureckie, owe „wściekłe hordy barbarzyńskiego wroga” mogące „spustoszyć wzdłuż i wszerz, wypalić i zniszczyć kwitnące narody, w sposób bardziej okrutny i straszny niż ongiś Attyla”, mają swoje wady. Działają dla podbojów, „chciwości, dla tkwiącego w ich umysłach przeświadczenia, żeby swą sektę krzewić orężem”, ale większość z nich jest niezdatna do wojny i nieuzbrojona. Znają się jednak Turcy na pracach fortyfikacyjnych, potrafią utrzymywać w tajemnicy swe plany wojenne, a ich wywiad:

...obfituje w najgorszych ludzi, którzy wyrzekli się naszej religii, także w Żydów, a ci pilnie i nie bez powodzenia starają się śledzić nasze sprawy.

Z drugiej strony walory bojowe chrześcijan są właściwie zaletami jedynie Polaków i Węgrów: zapał, męstwo, waleczność, wyszkolenie w posługiwaniu się bronią, mocne i dzielne konie, uzbrojenie jazdy w kopie. Dość anachronicznie brzmiały wywody Tarnowskiego o rozstrzygającej roli lekkiej jazdy i bitew w otwartym polu, nie pasujące już raczej do nowej rzeczywistości polowy XVI wieku. Oparte były one na jego własnych doświadczeniach sprzed dwudziestu lat i pasujące do walk stepowych z Tatarami.

Ta niechęć do cudzoziemskich dowódców i zachodniej piechoty widoczna była w praktycznej działalności Tarnowskiego, w jego antyniemieckiej postawie i w jego polityce kadrowej w wojsku. „Nie do wiary, jak bardzo jest on w duszy przeciwko Niemcom” — pisał w 1535 roku o przyszłym autorze słynnego Consilium rationis bellicae kanclerz Piotr Tomicki ${ }^{6}$. Już w roku 1527 sejm krakowski wprowadził warunek osiadłości jako wymóg przy dostępie do godności rotmistrzów obrony potocznej. Dowódcy pochodzenia niemieckiego byli w Polsce rzadkością, a instrukcje sejmikowe nakazywały wówczas posłom domagać się wygnania wszystkich Niemców z Polski. Typowo szlachecki punkt widzenia na kwestię cudzoziemską w armii koronnej podzielał inny znany wówczas teoretyk wojskowości, Stanisław Łaski. Zdawać by się mogło, że ten żołnierz walczący na Zachodzie przeciw Habsburgom przedstawi bardziej obiektywną ocenę wojska niemieckiego i węgierskiego. Tymczasem w dziele Spraw i postępków rycerskich i przewagi opisanie krótkie... ${ }^{7}$, ukończonym w 1545 roku, pochwalił on wprawdzie za wyszkolenie najemników

\footnotetext{
5 Ibidem, s. 308.

${ }^{6}$ Acta Tomiciana, t. 17, wyd. W. Pociecha, W. Urban, A. Wyczański, Wrocław-Kraków-Poznań 1966, s. 176; zob. M. Plcwczyński, W służbie polskiego króla..., op. cit., s. 166, 181-185, 198, 221; idem, Uwarunkowania obcych zaciqgóu'..., op. cit., s. $13-15$.

7 Zob. [S. Łaski], Spraw i postępków rycerskich i przewagi opisanie krótkie z naukami w tej zacnej zabaurie potrzebnymi, wyd. S. Karliński, Lwów 1599; Stanisława Łaskiego prace naukowe i dyplomatyczne, wyd. M. Malinowski, Wilno 1864:
} 
cesarskich Karola V, ale jednocześnie zaznaczył, że piechurzy niemieccy są często pijani, tak że „czasem na nogach stać nie mogą". Dał też swoistą charakterystykę nacji żołnierskich:

...żołnierz z gorących krajów ma więcej chytrości niż męstwa, bo mało krwie w sobie ma; wypali mu ją słońce, żal mu jej rozlać, chytrości a fortelów używa. A żołnierz z tych zimnych krajów ma w sobie krwie nazbyt, serca dosyć, rozumu mniej; a przecie też krwie nie żałuje, bo jej ma dosyć; rad ją rozleje gdzie potrzeba niesie $(. . .)^{8}$.

Zarówno Tarnowski, jak i Łaski — choć zapewne znane im były projekty Niccola Machiavellego zastąpienia najemnych wojsk milicją miast włoskich - nie wypowiadali się na temat narodowej siły zbrojnej. Wydaje się, że dylematu: pospolite ruszenie czy wojsko pieniężne w ogóle nie dostrzegali. Nie proponowali więc ogólniejszych rozwiązań dotyczących obcych zaciągów i pogranicznego osadnictwa wojskowego w oparciu o doświadczenia habsburskie. Uczynił to natomiast najwybitniejszy polski pisarz polityczny doby odrodzenia - Andrzej Frycz Modrzewski. W jego dziele O poprawie Rzeczypospolitej, wydanym w 1551 roku, sprawom obronności poświęcona była trzecia księga, O wojnie ${ }^{9}$. Modrzewski doceniał przeciwnika. Według niego, Turcy mają liczną artylerię i nie zaniedbują żadnych orężnych ćwiczeń. Tatar zaś „rozbój na naszych ziemiach uprawia”, „czyha na każdą sposobność do wojny”, „nie sieje, nie zbiera, uczciwej pracy się nie ima, a żyje $z$ łupu, niewiele też u niego znaczą prawa czy dotrzymywanie wiary". Takiemu nieprzyjacielowi chciał Modrzewski przeciwstawić wojsko zaciężne lub zreformowane pospolite ruszenie. Był jednak zwolennikiem korzystania wylącznie z żołnierza werbowanego w kraju. Pisal, że do cudzoziemskiego żołnierza najemnego

...nie można mieć takiego zaufania, ani tak wiele od niego żądać, ani występnych tak sprawiedliwie karać jak swoich; jeżeli zaś ten żołnierz dzielnie się spisuje, drożej opłacać go trzeba $(\ldots)^{10}$.

Chodzi nie tylko o to, że cudzoziemski żołnierz wynosi z kraju dużo pieniędzy, ale że poznawszy teren, na którym walczy, i sposób walki tych, którzy go wezwali, mógłby później wrócić jako nieprzyjaciel z własnej inicjatywy lub zaciągnięty przez innych. Wróg bowiem chętnie zaciąga żołnierza, który zna kraj, w jakim mają się toczyć walki. Z drugiej strony Modrzewski przyznaje, że jeśli Polska ma żołnierza niewyszkolonego, to w razie potrzeby musi albo posługiwać się własnym niewyćwiczonym i skazywać się na klęskę, albo też skądinąd sprowadzać wyszkolonego.

Od pokonanego przeciwnika domaga się jednak pisarz dostarczania posiłków zbrojnych na podstawie zawartych traktatów sojuszniczych. Akceptuje też przyjmowanie i otaczanie opieką

Proza polska wczesnego Renesansu 1510-1550, wyd. J. Krzyżanowski, Warszawa 1954, s. 459-475; Wypisy źródtowe do historii polskiej sztuki wojennej, z. 8A, Polskie piśmiennictwo ogólnowojskonte do roku 1764, opr. Z. Spicralski, Warszawa 1966, s. 11-25.

${ }^{8}$ [S. Easki], Spraw i postępków rycerskich i przewagi opisanie krótkie..., op. cit., s. 12.

9 Zob. A. Frycz Modrzewski, De Republica emendanda, Kraków 1551; wyd. K. Kumaniccki, Warszawa 1953; A. Frycz Modrzewski, Dzieła wszystkie, tł. E. Jędrkicwicz, t. 1, Warszawa 1953; Wypisy źródlowe ..., op. cit., s. 26-35.

${ }^{10}$ Wypisy źródlowe..., op. cit., s. 30. 
uchodźstwa politycznego z wrogiego Polsce państwa. Teoria pisarza oparta więc tu była na praktyce jagiellońskiej stosowanej już od dawna na gruncie wojskowym. Nienowy też, bo oparty na starych pomysłach Ostafiego Daszkiewicza, był projekt utworzenia na terenach pogranicznych osad wojskowych. Jeśli jednak twórca oddziałów kozackich widział w tych osadach miejscową ludność ruską, to polski szlachecki pisarz uważal, że po przyłączeniu obcego terytorium należy miejscową ludność w większości przesiedlać w głąb państwa, a na inkorporowanych terenach osadzać własnych żołnierzy z ubogiej szlachty. Modrzewski podkreślał, że pozostałych mieszkańców trzeba pozyskać i osłabić ich wrogie nastroje. Należy więc osadników polskich zachęcać do zawierania małżeństw, by nie czynili miejscowym krzywd i szkód. Pisarz dopuszczał możliwość uczestniczenia mieszkańców opanowanego kraju w wojsku polskim jedynie pod warunkiem, „gdy się ich wierność pokaże". Ten program asymilacji obcej, podbitej ludności zakładał więc również jej służbę w armii koronnej. Zainteresowano się nim szczególnie za granicą. Przełożono dzieło Modrzewskiego na język hiszpański dla króla Maksymiliana, syna cesarza Ferdynanda I, by mógł z niego praktycznie korzystać, szykując się do wojny z Turkami i tworząc osadnictwo wojskowe na pograniczu turecko-węgierskim (Militärgrenze).

Poglądy Modrzewskiego o wyższości żołnierza rodzimego nad obcym najemnikiem podzielał Reinhard Lorichius. W jego Ksiegach o wychowaniu i o ćwiczeniu każdego przetożonego..., przetłumaczonych na język polski w 1555 roku, a wydanych drukiem w roku 1558, znalazł się cały rozdział zatytułowany $O$ chytrych a misternych wojennych fortylach pańskich, czasu wojennego: jesli pan ma ufá́ poddanym suym niż cudzoziemcom, którzy za pieniq̨dze stużq ${ }^{11}$. Kolejnym teoretykiem wojskowości był książę pruski Albrecht Hohenzollern, który swoje Ksieggi o rycerskich rzeczach... ukończył w 1555 roku, a praca ta została przetłumaczona na język polski na polecenie króla Zygmunta Augusta przez Macieja Strubicza $\mathrm{w} 1561$ roku $^{12}$. Związany z hetmanem Janem Tarnowskim i pozostający pod jego wpływem Albrecht ze zrozumiałych względów uchylił się od oceny wartości cudzoziemskich żołnierzy. Niechętna wobec niego postawa szlachty polskiej, która nie dopuściła go do zasiadania w senacie koronnym, krępowała go zapewne w wyrażaniu niepopularnych uwag. Upust swym rzeczywistym poglądom dał już w rok po napisaniu swej pracy, gdy konflikt z zakonem inflanckim postawil go praktycznie w roli sponsora i organizatora zaciągów niemieckich dla króla polskiego ${ }^{13}$.

Od czasów wyprawy pozwolskiej 1557 roku można zaobserwować znaczny napływ cudzoziemskich oddziałów, które odcisnęły swe piętno na wojskowości i sztuce wojennej państwa polsko-litewskiego. Świadomie planowane i organizowane zaciagi obcych żołnierzy oraz współdziałanie sił sojuszniczych i posiłkowych w Inflantach i na Litwie stwarzały nowe problemy organizacyjne i międzyludzkie, które znalazły odbicie nawet w artykułach wojskowych. Właśnie

${ }^{11}$ Zob. R. Lorichius, Ksieggi o wychowaniu i ó ćwiczeniu każdego przełożonego..., Kraków 1558, k. 142v-159; J. Sikorski, Polskie piśmiennictwo wojskowe..., op. cit., s. 101-102.

${ }_{12}$ Zob. Albrecht Hohenzollern, Ksiegrio rycerskich rzeczach a sprawach wojentych, rps Biblioteki Czartoryskich w Krakowie, sygn. 1813.

${ }_{13}$ Zob. M. Plewczyński, Krzyżacy i prusacy ksiqżęcy w armii koronnej w latach 1497-1572, „Zeszyt Naukowy Ośrodka Badań Historii Wojskowcj Muzeum Wojska w Białymstoku” 1998, nr 12, s. 41-43; idem, W stużbie polskiego króla..., op. cit., s. 190-210. 
w formie artykułów obowiązujących w obozie zaciężnych polskich pod Selburgem nad Dźwiną w 1561 roku wydana została praca Floriana Zebrzydowskiego Pouczenie wojenne, napisana jeszcze w 1559 roku i przesłana hetmanowi wielkiemu litewskiemu Mikołajowi Radziwiłłowi Rude$\mathrm{mu}^{14}$. Hetman zabraniał w niej żołnierzom polskim konfliktów i zwad z Litwinami i Inflantczykami. Motywacja była prosta: ,jednegośmy pana i jedniśmy ludzie” i dlatego powinniśmy się nawzajem „czcić, szanować i miłować”.

W warunkach toczących się dyskusji nad unią polsko-litewską i obronnością Ukrainy ukazał się w latach 1567-1568 utwór Mikołaja Reja Spólne narzekanie wszej Korony na porzq̨dnq niedbałość naszq ${ }^{15}$. Pisarz powrócił w nim do dawnych pomysłów Modrzewskiego rozdania polskiej ubogiej szlachcie ziemi na terenach pogranicznych w zamian za obowiązek ich obrony. Kordon graniczny stanowić miał doraźne zabezpieczenie, natomiast stałą służbę wojskową pełnić miały kolejno ziemie koronne. Mimo że Kozaczyzna ukrainna wyrosła już na niezależną siłę zbrojną, nie spotykamy o niej ani słowa w utworze Reja.

Nie zauważył też walorów bojowych Kozaków niżowych znany pisarz wojskowy Marcin Bielski, choć w Sprawie rycerskiej... wydanej w roku 1569 dał przegląd wszystkich sąsiednich nacji żołnierskich ${ }^{16}$. Osobiście walczył w młodości z Tatarami i Mołdawianami, ale przedstawił również wojskowość niemiecką, moskiewską, węgierską, a nawet włoską i hiszpańską. Opisy uzbrojenia, wyposażenia i ubiorów wojskowych narodowości ościennych miały u niego na celu uchwycenie nie tylko wartości i walorów bojowych, ale również cech i predyspozycji wojskowych poszczególnych nacji. Najwyżej Bielski oceniał przeciwnika wschodniego. Podkreślał zwłaszcza waleczność i zdyscyplinowanie żołnierzy tureckich. W wojsku sułtańskim bowiem:

...wielka sprawiedliwość, zachowanie w pokoju, milczenie, niedrapierstwo, bo nad takimi wielką srogość pokazują. Nigdy u nich nie usłyszy zwady jakiej, ani słowem, ani bronią, ani przewierzenia. Nic inszego nie biorą przed się, jedno jakby się w męstwie starszemu okazał, bo takie dobrym datkiem i urzędem opatrują. Wiele obyczajów lepszych mają niż krześcianie w tych rzeczach. A to jedno: iż każdy $z$ chucią posłuszen starszego swego, chocia z prostego narodu będzie, których bardzo wiele nad sobą mają jako niegdy Rzymianie. Drugie, iż żadnej bojaźni śmierci u nich nie masz (...) Trzecie, iż są mierniejsi w piciu i jedzeniu, bo się małą rzeczą wychowają $(\ldots)^{17}$.

\footnotetext{
${ }^{14}$ Zob. Polskie ustawy i antykuty wojskowe od XV do XVIII w., wyd. S. Kuttrzcba, „Archiwum Komisji Historii Wojskowości PAU”, t. 3, Kraków 1937, s. 78; Materiały do działalności wojskowej Floriana Zebrzydou'skiego, wyd. J. Jasnowski, „Przegląd Historyczno-Wojskowy" 1939, t. 9, s. 275 i n.

${ }_{15}$ Zob. [M. Rej], Spólne narzekanie wszej Korony na porzqdnq niedbatośc nuszq, w: idem, Zwierciadto albo ksztatt, w' którym każdy stan snadnie się może surym sprawam jako we zwierciadle przypatrzé, Kraków 1567-1568; wyd. J. Kallenbach, Warszawa 1903-1904.

${ }^{16}$ Zob. M. Biclski, Sprawa rycerska wedlug postępku i zachowania starego obyczaju..., Kraków 1569; wyd. K. W. Wójcicki, Archiwum domowe do dziejów i literatury krajowej, Warszawa 1856, s. 183-348; Wypisy źródlowe ..., op. cit., s. 49-68; J. Sikorski, Polskie piśmiennictwo wojskowe..., op. cit., s. 93-100.

${ }_{17}$ Wypisy źródłowe..., op. cit., s. 58.
} 
Pod względem bojowym zainteresowanie Bielskiego wzbudzała przede wszystkim piechota turecka:

...schulacy albo solachi, a ci są strzelcy dobrzy z luku (...). Janczarowie drudzy

miasto łuku arkebuzy noszą, z których bardzo miernie strzelają (...).

Świetnymi łucznikami byli też Tatarzy, którzy „tężej” strzelali uciekając, niż się „potykając”. Ci ostatni wzbudzali podziw u pisarza swą czujnością, szybkością i odpornością na głód, zimno, brak snu i wypoczynku.

Według Bielskiego żołnierze moskiewscy wytrzymałością dorównywali Tatarom, a dyscypliną Turkom:

...ma Moskwa swe dary osobne w rzeczach rycerskich, że są czujni, opatrzni, posłuszni, nędzę i niewczas wytrwają jako jest głód, zimno, gorącość, mokrość; karność wielka, posłuszeństwo, zgoda ${ }^{18}$.

W walkach często stosują podstępy i zasadzki. Najbardziej wartościowi są piechurzy moskiewscy uzbrojeni w liczne rusznice, którymi umiejętnie potrafią się posługiwać i szybko je ładować. Skuteczni są zwłaszcza w trudnym ruskim terenie pokrytym licznymi lasami, błotami, jeziorami i rzekami. Na wysokim poziomie stoi rzemiosło zbrojeniowe (,rzemieślnicy pilni”), inżynieria wojskowa i artyleria obsługiwana przez puszkarzy sprowadzanych z Niemiec, Prus, Inflant, Szwecji i niewypuszczanych z Rosji. Lepsi są więc żołnierze moskiewscy w walkach oblężniczych, zwłaszcza w obronie zamków, niż w bitwach toczonych w otwartym polu. Stąd słabsza jazda, zbyt wolna, ale za to na koniach dobrych na podmokłe tereny.

Niejednoznaczną opinię wystawił Bielski Mołdawianom. Z jednej strony jest to „wojsko nie światłe”, słabo uzbrojeni „chłopi prości od pługa i dobytka”, z drugiej zaś — to żołnierze dzielni, dobrze walczący osęką, kopią i tarczą, na koniach „równych” i szybkich, a artyleria ich liczna z niemieckimi szybkostrzelnymi działkami. Z południowych sąsiadów Polski na pozytywną ocenę pisarza zasłużyli Węgrzy. Husarze węgierscy „potykają” się z nieprzyjacielem „dobrze i ze wszego skoku”, jednak „nie chcą w jednym szyku z innymi narodami stawać, nie są też im życzliwi, zwłaszcza Niemcom". Piechota rekrutuje się z różnych narodowości, a szczególną wartością bojową ("skocznością") odznaczają się hajducy, martolosi i piechurzy słowaccy. Od Serbów (Raców) wzięli wprawdzie Polacy obyczaj walki z „drzewem i tarczą”, ale później ich „odprawili”, ponieważ „im szkody czynili”. Wspomniał też pisarz o Czeremisach, którzy zbrojni w arkebuzy służyli w wojsku polskim i „wiele posług dobrych okazowali, czyniąc z Tatary”.

Znacznie skromniej przedstawiał się w pracy Bielskiego obraz żołnierzy zachodnich. U Niemców liczniejsza od jazdy jest piechota, „w dostatecznej zbroi i z strzelbą dobrą ruśniczą”, bo w niej „pokładają wszystkę nadzieję swoją”, stojąc za nią jak za murem. Znają się na pracach fortyfikacyjnych, dobrze obwarowując obozy wojenne. Są dobrze uzbrojeni i wyposażeni, ale zawodzi

\footnotetext{
18 Ibidem, s. 62.
} 
u nich dyscyplina. Gdy nie otrzymują w terminie żołdu, masowo opuszczają szeregi. Podobnie negatywną opinię wyrazil pisarz o Włochach, natomiast z uznaniem wypowiedział się o bojowości Hiszpanów. Widoczny jest brak zaufania do żołnierzy przybywających z Zachodu. Radził na przykład Bielski, by w czasie walki zwracać uwagę na cudzoziemskich puszkarzy, którzy łatwo dają się przekupić i porozumiawszy się z nieprzyjacielem, wystrzeliwują listy na oblężony zamek lub do miasta, przesyłając wiadomości przeciwnikowi.

W Sprawie rycerskiej... znaleźć można więcej krytycznych uwag odnoszących się do ewentualnych sojuszników, natomiast pozytywne oceny dotyczą głównie przeciwników wojska polskiego. Te ostatnie służyły bowiem poznaniu walorów nieprzyjaciela w celu skuteczniejszej z nim walki. Brak u Bielskiego szerszych programów, postulatów na przyszłość i roztrząsania współczesnych mu systemów obronnych. Uważał on jedynie, że lepiej i bezpieczniej jest szkolić własne wojsko. Ono jest bowiem warunkiem potęgi państwa, a nie cudzoziemskie wojsko najemne. Twierdził, że wszystko co złe, płynie do nas z zagranicy. Niewątpliwie musiał pisarz wiedzieć o akcjach werbunkowych w czasie pierwszej wojny północnej (1560-1570), o knechtach niemieckich sprowadzanych do Inflant, o przyjmowaniu na żołd koronny uciekinierów moskiewskich, wreszcie o zaciągach kozackich, węgierskich czy czerkieskich. W kwestii werbunku obcych żołnierzy praktyka wyprzedziła teorię wojskową. Bielski, podążając śladem Tarnowskiego, nie doceniał frontu północno-wschodniego, i opowiadając się za wojskiem wyłącznie narodowego charakteru, nie wyciągał nasuwających się w sposób oczywisty wniosków. Działo się to w okresie, kiedy w Niemczech nie udały się próby (podejmowane przede wszystkim przez Leonarda de Schwendii w 1558 roku) zastąpienia wojsk najemnych i zaciężnych żołnierzem pochodzącym z poboru. Podstawową jego wadą był brak wyszkolenia i doświadczenia bojowego.

Od początku lat siedemdziesiątych XVI wieku pisarze w większym stopniu zajmowali się bieżącymi sprawami, żywo reagowali na zmieniającą się rzeczywistość polityczno-wojskową. Rzeczypospolita po unii lubelskiej stała się trójnarodowym imponującym państwem, w którym sprawy wojskowe uległy daleko idącym przeobrażeniom. Większość dotychczasowych reformatorów $\mathrm{w}$ aspekcie zmiany struktury organizacyjnej armii nie wyszła poza szlacheckie pospolite ruszenie. Pierwszym, który w zdecydowany sposób odrzucił myśl o nim, był Andrzej Ciesielski. W pracy Oratio ad Equites ${ }^{19}$, wydanej w 1572 roku, stwierdził, że stałe wojsko ma się składać wyłącznie z oddziałów zaciężnych. Autor oparł się przy tym na wzorach istniejących już w innych państwach europejskich.

W latach $1577-1578$ powstały Księi hetmańskie Stanisława Sarnickiego ${ }^{20}$. Na twórczość pisarską tego znanego teoretyka wojskowości wpływ miala zachodnioeuropejska praktyka wojenna i znane mu traktaty wojskowe wywodzące się z tamtego obszaru. Stąd Sarnicki umniejszał rolę jazdy w przyszłych działaniach wojennych, podkreślając trudności w pokonywaniu przez kawalerię przeszkód terenowych oraz łatwość jej pokonania wskutek wzrostu siły ognia piechoty.

19 Zob. S. Krzyżanowski, Andrzej Ciesielski. Studium z literatury politycznej XVI w., „Rocznik Filarccki”, Kraków 1886.

${ }^{20}$ Egz. Biblioteki Jagiellońskiej w Krakowie, rps 171; Archiwum Główne Akt Dawnych w Warszawic, Archiwum Publiczne Potockich, rps 325; zob. J. Sikorski, „Ksiegi hetmańskie”..., op. cit., s. 9-16. 
W Ksieggach hetmaniskich znaleźć można pozytywny obraz wojskowości zachodniej, w szczególności niemieckiej. Autor wskazywał na doskonały system zaopatrzenia w żywność, organizację przemarszów i urządzania obozów w armii niemieckiej, francuskiej i tureckiej, wysoki poziom sztuki oblężniczej na Zachodzie i inżynierii wojskowej w Turcji. Powoływał się na przykłady dużych możliwości mobilizacyjnych piechoty niemieckiej. W Niemczech i we Włoszech normalnością było zebranie 40-80 tys. piechurów, gdy tymczasem w Polsce takie akcje werbunkowe były niemożliwe. Jedyny zarzut czynił Sarnicki żołnierzom niemieckim za niską wśród nich dyscyplinę. Wspomniał, że w Niemczech i Czechach było tak wielu dowódców, że i Polacy do nich „po hetmany i po mierniczych zamkowych posyłali”. Pisarz odnotował jedynie fakt odnoszący się do wojny północnej, ale nie zajął stanowiska w sprawie przeprowadzania obcych werbunków.

Postulowanie prowadzenia zaciagów poza granicami kraju i artykułowanie pozytywnych opinii o żołnierzach zachodnich mogło być bowiem sprzeczne z panującymi w Polsce nastrojami antygermańskimi, rodzącą się wśród szlachty italo-i hispanofobią. Jan Dymitr Solikowski z losów Czechów i Węgrów wyciągał wnioski, że Habsburgowie na tronie polskim „zbudująli zamek, dadzą rotę Hiszpanowi (...) a będą z nas choć zimni, a przecię Hiszpani”21 . Niemcy zostały pognębione przez „hiszpańskie ćwiczenia”, bo cesarz Karol V „nawiódł tam Hiszpanów, Węgrów, Włochów". Na ziemiach podległych Habsburgom — pisano w okresie pierwszego bezkrólewia „kto hetmanem, jako Niemiec, Hiszpan, Włoch?”. Niemieckiego lancknechta i hiszpańskiego muszkietera uważano za szermierzy absolutyzmu, a możliwość ich pobytu w Krakowie, Poznaniu czy Piotrkowie budziła niepokój. Stąd jedną z pierwszych uchwał zjazdu krakowskiego 17 lipca 1572 roku był zakaz trzymania w stolicy wojska cudzoziemskiego.

Na czoło zagadnień wojskowych omawianych przez pisarzy politycznych w końcu XVI wieku wysunęły się dwa: osadnictwo wojskowe i liga antyturecka. Za pogranicznym osadnictwem wojskowym opowiedział się w latach osiemdziesiątych Łukasz Górnicki, ale w Rozmowie Polaka $z$ Wtochem... przeciwny był Kozakom niżowym. Uważał, że więcej oni szkodzą, niż pomagają Rzeczypospolitej $^{22}$. Biskup kijowski Józef Wereszczyński w traktatach wydanych w latach 1592-1597 proponował rozłożenie na lenników Polski obowiązku dostarczania określonych rodzajów wojska. Północne krainy - Prusy, Kurlandia i Inflanty miały wystawić choragwie rajtarskie. Województwa kresowe dostarczać miały lekką jazdę kozacką, ale na Ukrainie pisarz projektował osiedlać krzyżaków i kawalerów maltańskich. Pozostali autorzy (Krzysztof Warszewicki, Piotr Grabowski), podpierając się przykładami rozwiązań stosowanych przez inne państwa, opowiadali się za osadnictwem wojskowym przy granicach, ale polskim, szlacheckim. Miało ono również utrzymać w karbach niesforne, buntujące się kozactwo. Dopuszczano służbę w stałej armii nawet chłopów, ale wykluczano z niej cudzoziemców, którym nie ufano.

${ }^{21}$ Zob. Pisma polityczne z czasów pierwszego bezkrólewia, wyd.J. Czubck, Kraków 1906, s. 420-421; J. Tazbir, Staropolskie opinie o Hiszpanach, „Przcgląd Historyczny” 1967, t. 58, s. 605-623.

22 Zob. E. Górnicki, Rozmowa Polaka z Wochem około elekcji i wolności, prawie, obyczajach i innych rzeczach, Sanok 1855 , s. 100 . 
Wyłania się pytanie, jak obraz kreślony przez teoretyków wojskowości i pisarzy politycznych przełożył się na faktyczną liczebność obcych nacji w armii koronnej. Okazuje się, że dobre wyszkolenie i umiejętności prowadzenia walk oblężniczych przeważyły nad brakiem zaufania do zachodniego żołnierza, wypływającego z jego niskiej dyscypliny. W rezultacie tylko za ostatnich Jagiellonów przewinęło się przez służbę królewską około 20 tys. kosztownych i przekupnych Niemców, mimo ich przysłowiowej — w odbiorze szlacheckim — skłonności do dezercji, zwad, grabieży, pijaństwa i rozpusty. Rzadko wspominani przez pisarzy „nierozumni” i „niewierni” Rusini czy buntujący się „niesforni” Kozacy wsparli w tym okresie Koronę około 7 tys. ludzi „mających serce do walki” i „krwi nie żałujących”. Pomijanych w pracach Czechów i Morawian doliczyć się można w szeregach 4 500, dzielnych choć "niewykształconych” i słabo uzbrojonych Mołdawian - 1600, a „konfliktowych” Litwinów - 1500. Równie „kłótliwych” i „nienawidzących innych narodów”, ale „mężnych” i „walecznych” Węgrów można szacować na około tysiąca żołnierzy. Podobny udział w służbie królewskiej mieli Tatarzy - ci „przeklęci”, „psiej krwi barbarzyńscy rozbójnicy", ale za to chytrzy, wyszkoleni i wytrzymali wojownicy ${ }^{23}$. Ogólnie wady Niemców przeważały nad ich zaletami. U przeciwnika wschodniego odwrotnie — żołnierze moskiewscy, tureccy i tatarscy mieli więcej cech dodatnich niz ujemnych.

Najobszerniej pisarze informowali czytelników o atrybutach wojskowych wrogich żołnierzy. Kreślony przez nich stereotyp doskonale walczącego, a jednocześnie okrutnego przeciwnika, dowodzi poznawczego i kształcącego charakteru szesnastowiecznego piśmiennictwa wojskowego. Brakło natomiast propozycji systemowych, uwidocznienia dominujących cech wojskowych u potencjalnych sojuszników polskich, które można by było wykorzystać w rozwiązaniach kadrowych i organizacyjnych. Jedynie Józef Wereszczyński widział możliwość użycia osadników niemieckich do walki z Tatarami. Zarówno on, jak i Modrzewski i Sarnicki postulowali też użycie w walkach wojsk sojuszniczych, lennych i złożonych z niepolskiego etnicznie elementu, zamieszkującego jednak wyłącznie w granicach Rzeczypospolitej. Teoretycy wojskowi i pisarze polityczni albo milczeli na temat obcych, cudzoziemskich zaciągów, albo je odrzucali. A tymczasem wiadomo, że odsetek cudzoziemców za ostatnich Jagiellonów w wielonarodowościowej armii królewskiej sięgał 30\%. Zaciąg cudzoziemski w Koronie w czasach króla Stefana Batorego objął $20 \%$ całości jazdy i $50-60 \%$ piechoty ${ }^{24}$. W postulowanej zatem koncepcji armii zaciężnej praktyka odbiegała wyraźnie od proponowanej teorii.

Czy więc pisarze nie widzieli kwestii narodowościowej w wojsku, czy też świadomie ją pomijali? Oczywiście wśród pisarzy polityczno-wojskowych brakło większej liczby badaczy związanych $z$ armią, którzy uchwyciliby postęp poza krajem i przenieśli informacje o rozwiązaniach praktycznych gdzie indziej stosowanych. Obowiązywał autorytet najwybitniejszych Modrzewskiego i Tarnowskiego, i na nich się też wzorowano. A ci faktycznie nie dopuszczali

${ }^{23}$ Zob. M. Plewczyński, $W$ stużbie polskiego króla..., op. cit., s. 201.

${ }^{24}$ Zob. H. Kotarski, Wojsko polsko-litewskie podczas wojny inflanckiej 1576-1582 r. Sprawy organizacyjne, cz. 5, SMHW 1972 , t. 18 , cz. 2, s. 49, 54-55, 66-67, 87-88. 
możliwości cudzoziemskich zaciagów. Przede wszystkim nie było jednak odpowiedniego, sprzyjającego zmianom, klimatu społeczno-politycznego.

Cala literatura pierwszej polowy XVI wieku wyplywała ze strategii obronnej. Dotychczasowy system wyszkolenia wojskowego był wystarczający do zwalczania krótkotrwałych, szybkich wtargnięć nieprzyjacielskich, a zwłaszcza najazdów tatarskich mających na celu łupy i wyniszczenie kraju. Sytuacja zmieniła się, gdy w związku z polityką Zygmunta Augusta od połowy XVI stulecia praktyka inflancka poczęła dyktować działania zaczepne, przenoszenie działań na obce terytorium. Zmiana charakteru działań spowodowała, że teoria i praktyka okazały się niewystarczające do sprostania nowym wymogom pola walki. Praktyka musiała się do nowej sytuacji szybko dostosować, przynajmniej w ograniczonym zakresie. Teoria nie mogła za tymi zmianami nadążyć, bo miała większe bariery do pokonania ${ }^{25}$. Nie tylko lata dwudzieste XVII wieku, ale wcześniej już lata pięćdziesiąte i sześćdziesiąte wieku XVI wykazały konieczność zweryfikowania dotychczasowych sądów co do roli piechoty i artylerii. Przeciwnik szwedzki i moskiewski dążył do zdobycia i utrzymania na stałe części terytorium, mial wyszkoloną i zdyscyplinowaną piechotę dysponującą silnym ogniem, współdziałającą z jazdą, rozbudowaną i skuteczną artylerię, posługiwał się polowymi fortyfikacjami i potrafil umiejętnie bronić i zdobywać stałe punkty oporu. Nie można z nim było walczyć sposobami dawniej wypróbowanymi. Mimo to polska myśl teoretyczno-wojskowa nie zmieniła swych podstawowych założeń. Pozostała w stereotypie niesfornych i wiarołomnych najemników niemieckich i węgierskich. Wynikało to z braku wybitnej indywidualności wśród pisarzy wojskowych, którzy nie tworzyli określonego klimatu w społeczeństwie szlacheckim i nie doceniali zawodowego, wyszkolonego i dobrze uzbrojonego żołnierza zachodniego.

Brak nacisku na teorię w kwestii cudzoziemskiej wynikał także $z$ zasad ustrojowych państwa. Pospolite ruszenie utrzymywano z powodów politycznych. Szlachta miała być nadal tą warstwą narodu, która broni państwa i w związku z tym należą się jej przywileje. Dla pisarzy politycznych szlacheckiego rodowodu racje stanowe i troska o nienaruszalność podstaw ustrojowych państwa były wartościami nadrzędnymi w stosunku do wymogów stawianych przez pole walki. Spośród uwarunkowań politycznych, które nie sprzyjały poruszaniu kwestii zaciagów cudzoziemskich wymienić należy nastroje szlacheckie niechętne Habsburgom, Niemcom, Włochom i Hiszpanom, ograniczanie cudzoziemcom awansu wojskowego i cywilnego, ponieważ szlachta uważała ich za potencjalnych konkurentów w dążeniach do urzędów, wreszcie straszak absolutyzmu, który kazał widzieć w rozbudowanym przez oddziały cudzoziemskie wojsku nadwornym próbę wzmocnienia władzy królewskiej ${ }^{26}$. W kwestiach osadnictwa wojskowego wzdłuż Dniepru akceptowała szlachta - a w ślad za nią pisarze polityczno-wojskowi - jego polski, narodowy charakter. Widoczny był społeczny aspekt w całej (poza Sarnickim i Wereszczyńskim) twórczości pisarskiej w odniesieniu zwłaszcza do ruskich chłopów i Kozaków, co znalazło odbicie w ustawodawstwie hamującym obce osadnictwo wojskowe.

${ }_{25}$ Zob. K. Olejnik, Rozwój polskiej mysili wojskouej..., passim.

26 Zob. M. Plcwczyński, Uu'arunkowania obcych zaciqgów..., op. cit., passim; idem, $W$ stużbie polskiego krola..., op. cit., s. $220-233$. 
Ten aspekt negatywnych uwarunkowań nie sprzyjał występowaniu z programami zaciągów cudzoziemskich lub wciągnięcia nacji obcego pochodzenia z ziem polskich do służby koronnej. Teoretyk publicznie występujący z takimi propozycjami mógł się znaleźć jakby poza nawiasem politycznym, stanowiącym o jego przynależności stanowej. Z drugiej strony utrwalał się negatywny stereotyp Niemca i Kozaka, a mniemanie o wyższości bojowej żołnierza moskiewskiego, tureckiego i tatarskiego wzrastało. Dowódcy nie mogli znaleźć w piśmiennictwie wojskowym jednoznacznych opinii o wartości wojskowej Czechów, Mołdawian, Litwinów, Serbów, Włochów czy Francuzów. Będąc zaś odpowiedzialni za skuteczność działań wojennych, kierowali się własnymi odczuciami i doświadczeniami, nie zawsze zgodnymi z obiegowymi opiniami. Nic więc dziwnego, że rozdźwięk między praktyką a teorią stale się pogłębiał. 